Short communications

\section{The removal of ${ }^{14} \mathrm{C}$-edrophonium} from the circulation

\author{
D. J. BACK and T. N. CALVEY
}

\section{Department of Pharmacology and General Therapeutics, University of Liverpool, Liverpool L69 3BX}

The clearance of ${ }^{14} \mathrm{C}$-edrophonium from plasma was studied in the rat. Distribution studies showed that $5 \mathrm{~min}$ after intravenous injection of the drug, more than half the dose was present in the liver and the kidneys. The concentration in these organs was approximately 20 times the level in other tissues. The plasma concentration of ${ }^{14} \mathrm{C}$-edrophonium was invariably expressed as the sum of two exponential terms, suggesting that the drug may return to the circulation from other tissues as the plasma level falls.

Many recent studies have been primarily concerned with the kinetics of lipidsoluble compounds that are slowly metabolized and excreted. After intravenous administration, the disappearance of these drugs from plasma is usually consistent with an initially rapid rate of loss from a central compartment, followed by pseudo-distribution equilibrium between the central and a peripheral compartment. Few investigations have been concerned with the clearance from plasma of quaternary amines, which are only distributed in a single and well-defined central compartment, and are primarily eliminated from this compartment.

The present paper is mainly concerned with the clearance of ${ }^{14} \mathrm{C}$-edrophonium chloride from the circulation in the rat. Since this quaternary amine combines reversibly with chelinesterase, its evanescent effects on neuromuscular function (Randall, 1950 ; Hobbiger, 1952) are presumably due to a rapid decline in the concentration in blood. Although these experiments confirmed that ${ }^{14} \mathrm{C}$-edrophonium was rapidly removed from the circulation by both the liver and the kidneys, its concentration in plasma was not described by the mono-exponential decline predicted from theoretical considerations.
Methods.-Wistar rats of either sex were anaesthetized with urethane (approximately $1.4 \mathrm{~g} / \mathrm{kg}$, i.p.) and a femoral vein was cannulated with polyethylene tubing. Animals were killed $5 \mathrm{~min}$ after intravenous injection of ${ }^{14} \mathrm{C}$-edrophonium chloride, (ethyl[1-14 C]dimethyl-(3-hydroxyphenyl)ammonium chloride, specific activity $10.0 \mathrm{mCi} / \mathrm{mmol} ; 2.0 \mu \mathrm{mol} / \mathrm{kg}$ ), and the liver and both kidneys were removed and weighed. Small specimens (50-100 mg) of most tissues and organs were excised, weighed, and placed in liquid scintillation vials. Samples were solubilized in methanolic hyamine hydroxide (Hyamine 10-X ; $2.0 \mathrm{ml}$ ), and decolourized by treatment with hydrogen peroxide (Herberg, 1960) prior to liquid scintillation spectrometry. Counting efficiencies were determined by internal standardization.

In a separate series of experiments, anaesthetized Wistar rats were injected with ${ }^{14} \mathrm{C}$-edrophonium chloride $(4.0 \mu \mathrm{mol} /$ $\mathrm{kg}$, i.v.). Specimens of heparinized blood (approximately $0.2 \mathrm{ml}$ ) were obtained by means of a carotid arterial cannula 5-95 min after administration. After centrifugation, the total radioactivity in samples of plasma (usually $25 \mu \mathrm{l}$ ) was counted at an efficiency of approximately $90 \%$, with a ${ }^{133} \mathrm{Ba}$ external standard. ${ }^{14} \mathrm{C}$-edrophonium was separated from its metabolites in plasma by paper chromatography, and the radiochromatograms were subsequently counted by liquid scintillation spectrometry (Back \& Calvey, 1972). The concentration of unchanged ${ }^{14} \mathrm{C}$-edrophonium was then determined from the total radioactivity in plasma and the results of paper chromatography.

Unless otherwise stated, results are expressed as the mean \pm S.E.M. of at least 5 experiments.

Results.-High levels of radioactivity were detected in the liver $(343 \pm 105 \mathrm{nCi} / \mathrm{g})$ and the kidney $(573 \pm 116 \mathrm{nCi} / \mathrm{g}) 5 \mathrm{~min}$ after intravenous injection of ${ }^{14} \mathrm{C}$-edrophonium. These organs contained over half the administered dose of edrophonium $(32.2 \pm 5.4 \%$ in the liver and $18.1 \pm 2.6 \%$ in the kidneys). The concentration of radioactivity in the small intestine $(42 \mathrm{nCi} /$ g) and the bladder $(40 \mathrm{nCi} / \mathrm{g})$ was approximately twice as great as the maximum level in any other tissue or organ (range= 0-18 $\mathrm{nCi} / \mathrm{g}$ ), although the contents of these organs were not included during measurements of radioactivity. 
The concentration of unchanged ${ }^{14} \mathrm{C}$ edrophonium in plasma 5-95 min after intravenous administration of the drug is shown in Figure 1. Each graph represents the results of a single experiment. The plasma level rapidly decreased between 5 and $55 \mathrm{~min}$ (from $2 \cdot 60 \pm 0.28 \mu \mathrm{mol} /$ litre to $0.12 \pm 0.02 \mu \mathrm{mol} /$ litre) ; in contrast, between 55 and 95 min there was little change in the concentration of ${ }^{14} \mathrm{C}$-edrophonium in plasma. Consequently, a semilogarithmic plot relating ${ }^{14} \mathrm{C}$-edrophonium concentration to time (Fig. 1) was invariably resolved into two exponential components by the method of residuals (Riggs, 1963). An initial rapid phase of elimination (mean half life $=8.3 \mathrm{~min}$; range $=6.3-13.5 \mathrm{~min}$ ) was followed by a much slower decline, corresponding to the fall in the plasma concentration between 55 and 95 minutes.

In all experiments, the apparent volume of distribution of ${ }^{14} \mathrm{C}$-edrophonium was calculated from the equation

$$
V=\frac{\text { dose }}{A+B}
$$

where $V$ is the volume of distribution, and $A$ and $B$ are the intercepts of the two exponential functions on the ordinate at zero time. The values obtained $(1,508 \pm$ $260 \mathrm{ml} / \mathrm{kg}$ ) were approximately 6 times greater than accepted values for extracellular fluid volume.

Discussion.-In general, most cell membranes are almost impermeable to quaternary amines, and their elimination from the body is primarily dependent on carrier transport in the kidney (Peters, 1960) or the liver (Schanker \& Solomon, 1963), although some low molecular weight quaternary amines are extensively metabolized (Somani, Wright \& Calvey, 1970 ; Back \& Calvey, 1972). In the present experiments, the high apparent volume of distribution (approximately six times greater than extracellular fluid volume) presumably reflects extensive tissue localization or excretion of the drug. Distribution studies showed that more than half the dose of ${ }^{14} \mathrm{C}$-edrophonium was detected in renal and hepatic tissue within $5 \mathrm{~min}$

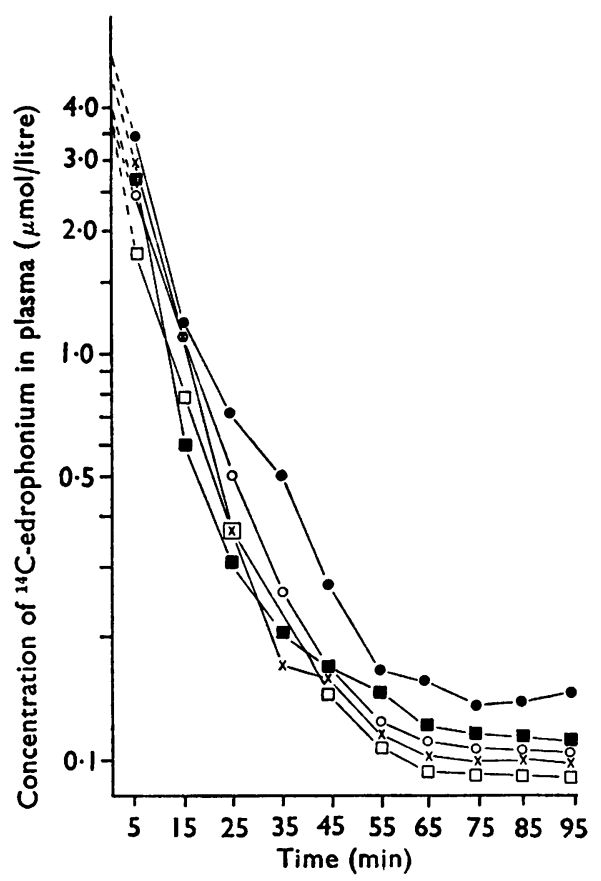

FIG. 1. The concentration of ${ }^{14} \mathrm{C}$-edrophonium in plasma after intravenous administration of the drug $(4 \cdot 0 \mu \mathrm{mol} / \mathrm{kg})$. The unchanged drug was separated from its metabolites in plasma by paper chromatography. Each graph represents the results of a single experiment; the intercept of the dotted line on the ordinate represents the theoretical concentration at zero time. 
of intravenous administration, confirming that the drug is rapidly removed from the circulation by these organs. Significant amounts of radioactivity were not present in other tissues.

In view of the virtual exclusion of ${ }^{14} \mathrm{C}$ edrophonium from most cells in the body, it was anticipated that the plasma concentration of ${ }^{14} \mathrm{C}$-edrophonium would be described by a single exponential function of time, corresponding to the clearance of the drug from extracellular fluid by metabolism and excretion. Despite these considerations, the concentration of ${ }^{14} \mathrm{C}$ edrophonium in plasma was invariably resolved into two exponential components, suggesting that the rapid uptake of the drug by kidney and liver was not adequately described in terms of a unidirectional elimination process. The second exponential component reflects the extremely slow decline in the concentration of ${ }^{14} \mathrm{C}$-edrophonium in plasma between 55 and $95 \mathrm{~min}$; this component has an extremely long half-life, and is consistent with the slow return of the drug to the circulation from a tissue compartment as the concentration in blood falls. Some other quaternary amines (for instance decamethonium) are also cleared from plasma in a similar manner, possibly owing to their initial uptake by, and subsequent release from, skeletal muscle (Giovanella, Manni, Mazzoni \& Moricca, 1961); one hour after intravenous injection of ${ }^{14} \mathrm{C}$ decamethonium, approximately $75 \%$ of the dose is present in striated muscle (Christensen, 1965). Similar factors are unlikely to apply to ${ }^{14} \mathrm{C}$-edrophonium, since the concentration of the drug in skeletal muscle is extremely low compared to the level in hepatic or renal tissue. Alternatively, it is possible that the quaternary amine is both secreted into and reabsorbed from the proximal tubular cells in the kidney by a process that is dependent on the plasma level of the drug, as has been reported for $p$-aminohippurate and other organic anions (Baines, Gottschalk \& Lassiter, 1968 ; Cho \& Cafruny, 1970 ; May \& Weiner, 1970). Another possibility is that the uptake of ${ }^{14} \mathrm{C}$-edrophonium by the liver is not a unidirectional elimination process. In future experiments, it is hoped to investigate which of these various explanations is correct.

This investigation was supported by a generous grant from the Peel Medical Research Trust. The skilled technical assistance of Mrs. L. Hughes is gratefully acknowledged.

\section{REFERENCES}

BaCK, D. J. \& Calvey, T. N. (1972). Excretion of ${ }^{14} \mathrm{C}$-edrophonium and its metabolites in bile: the role of the liver cell and the peribiliary vascular plexus. Br.J. Pharmac., 44, 534-543.

Baines, A. D., GotTschalk, C. W. \& LAssiter, W. E. (1968). Microinjection study of p-aminohippurate excretion by rat kidneys. Am. J. Physiol., 214, 703-709.

Cho, K. C. \& CafrunY, E. J. (1970). Renal tubular reabsorption of $p$-aminohippuric acid (PAH) in the dog. J. Pharmac. exp. Ther., 173, 1-12.

Christensen, C. B. (1965). Distribution and biliary excretion of decamethonium in doubly nephrectomized rabbits. Acta pharmac. et toxicol., 23, 275-286.

Giovanella, B., Manni, P., Mazzoni, P. \& MORICCA, G. (1961). Experimental studies on the fate of decamethonium. Can. Anaes. Soc. J., 8, 458-467.

HerberG, R. J. (1960). Determination of carbon-14 and tritium in blood and other tissues. Analyt. Chem., 32, 42-46.

HobBiger, F. (1952). The mechanism of anticurare action of certain neostigmine analogues. Br. J. Pharmac. Chemother., 7, 223-236.

MAY, D. G. \& Weiner, I. M. (1970). Bidirectional active transport of $m$-hydroxybenzoate in proximal tubule of dogs. Am. J. Physiol., 218, 430-436.

Peters, L. (1960). Renal tubular excretion of organic bases. Pharmac. Rev., 12, 1-35.

RANDALL, L. O. (1950). Anticurare action of phenolic quaternary ammonium salts. $J$. Pharmac. exp. Ther., 100, 83-93.

RigGs, D. S. (1963). The Mathematical Approach to Physiological Problems, pp. 146-161. Baltimore: The Williams and Wilkins Company.

Schanker, L. S. \& Solomon, H. M. (1963). Active transport of quaternary ammonium compounds into bile. Am. J. Physiol., 204, 829-832.

Somani, S. M., Wright, A. \& Calvey, T. N. (1970). The biliary excretion of trimethyl${ }^{14} \mathrm{C}$ (3-hydroxyphenyl)ammonium iodide and its metabolic products. Eur. J. Pharmac., 12, 109-113.

(Received March 4, 1972) 